\title{
Educommunication, Geography and Virtual Games: A Proposal to Encourage Scientific Literacy in Middle School
}

\author{
Émerson dos Reis Pereira, Andréa Goulart Mendes Carruba, Adam Gonçalves Zeni de Oliveira, \\ Jairo Aparecido Martins, and Estaner Claro Romão
}

\section{ABSTRACT}

This research describes a development process of an educommunicational project and its presentation by $7^{\text {th }}$ year's students of Middle School. Student's part of this research was from a private school in a city part of Sao Paulo's State. In fact, it aimed to verify possible contributions obtained by using a specific didactic sequence linked with Geography teaching. Thereunto, virtual games and educommunication tools were used to promote literacy and scientific dissemination through Digital Information Technologies and Communication. In terms of method utilized, a qualitative-descriptive method was used since it applied observation, analysis, and data comparison to obtain results. In addition, the methodology helped to solve problems throughout the project phase until it reached its final presentation. As a final result of this project, it was observed that students could develop not only active learning but also creative learning throughout the process. As assistance, students had teacher acting as a mediator in order to constantly guide and manage them in their activities. To sum up, documentary videos presented by students, combined with games and digital educational technologies are considered relevant forms of communication as well as effective learning resources because they favor a development of critical-scientific thinking. As a matter of fact, it is applicable when carrying out researches, experiencing challenges also building knowledge throughout student's own experience processes.

Keywords: Educommunication; Educational Games; Digital Technology; Collaborative learning; Geography.
Published Online: June 25, 2021

ISSN: $2736-4534$

DOI : 10.24018/ejedu.2021.2.3.116

\section{E. R. Pereira}

University of São Paulo, São Paulo, Brazil.

(e-mail: emersonpereira@ usp.br)

A. G. M. Carruba

University of São Paulo, São Paulo, Brazil.

(e-mail: andrea_goulart71@usp.br)

A. G. Z. Oliveira

University of São Paulo, São Paulo, Brazil.

(e-mail: adamfuzy@usp.br)

J. A. Martins

Waterloo, Canadá.

(e-mail: jairophd@gmail.com)

E. C. Romão*

University of São Paulo, São Paulo, Brazil.

(e-mail: estaner23@usp.br)

*Corresponding Author

\section{INTRODUCTION}

Twenty first century education presents a new standard in knowledge's construction as a result of intense technological transformations that occur regularly in new spaces [1]. In this sense, digital technology can be used as a tool to help individuals participating and interacting with people and processes, avoiding a sense of emergency even with environments in constant changes and reconfigurations.

Along a few decades, the called "digital natives" are part of a generation that seems to use digital technologies naturally and manipulate devices such as computers, smartphones, as well as digital games naturally. Such familiarity with devices has resulted a few divergences with traditional didactic dynamics, portraying little interactivity and favoring student dispersion during school classes [2].

In fact, motivation is the energy that drives also affects learning processes. According to Moraes \& Varela [3], when a teacher recognizes and invests in the student's interest, motivation with learning process is reinforced, fortunate, a commitment is established between parties, which ends up with activities successfully accomplished. In addition, authors reinforce that students feel recognized and predisposed to striving when they can demonstrate their evolution by reaching results.

Unfortunately, the pandemic caused by COVID-19 [1] placed several challenges to society in general, including how to manage students' education. So that, a big challenge was the creation of an attractive environment that would be able to promote a remote learning of pedagogical content, based on the Common National Curricular Base - BNCC [2].

In the current scenario, due to the pandemic of COVID-19 [1], this research takes into account that an electronic game can contribute to the teaching of Geography, promoting interaction and cognitive stimulation of students, through learning meaningful and pleasurable.

To sum up, the present work aimed to present the contributions resulted from a didactic sequence for the literacy and scientific dissemination of middle school students through Educommunication. Specific objectives listed are to verify the functionality of an online gambling as a facilitating resource in the learning process, and social interaction among students, making learning more meaningful and enjoyable. Also aimed to demonstrate and 
use different technological tools to learn how to look for reliable sources and statistical data for each Brazilian region. In addition, to establish relations about landscapes and territorial formation in Brazil, thereafter, comparing some transformations and differences among regions on Brazilian territory.

\section{THEORETICAL FUNDAMENTALS}

An approximation of communication to education requires different pedagogical models that objective to develop intervention's strategies for new cultural standards. So that, this approximation has to manage critical insertion in society to adapt it to media and educational processes [6]. In this context, the media can be seen as an instrument to promote judgment, critical sense, hypothetical and deductive thinking, as well as faculties for observation and research [7] (p. 128).

Educommunication is a form of education that uses digital technological resources to develop a collective work of documentary videos to provide a students' understanding about an environment that they are inserted. Still, Soares [8] emphasizes that the material produced from it has to comply with scientific truth, associating it with citizenship. Another characteristic of Educommunication is a technological mediation, because

[...] it contemplates the study of changes resulted from an incidence of technological innovations in the daily lives of people and social groups, as well as the use of information tools in educational processes, whether in person or at distance ([9], p. 06, our translation).

Meanwhile, the Digital Information and Communication Technologies have established important changes in the learning process due to the ease access to knowledge and changes in form of interaction, communication, and socialization between people [10].

Corroborating with the author, Levy [11] explains that with the advent of digital technologies, a new learning process appears to be linked to a cyber world, where student faces a range of possibilities to perceive and understand his/her reality when exploring, producing and disseminating knowledge.

This research consists of a didactic sequence, which according to Zaballa [12], is a set of ordered activities, with strategies and interventions, planned by a teacher and carried out by students. The purpose of this research is to help students to understand a content or problem and thereafter being able to provide answers and proposed solutions for problems [13].

Although teachers have to accomplish a pedagogical content previously established within a period, they have a possibility to create a structure and apply a sequence of activities during classrooms. The aim is student's learning added with a possibility to explore students' intellectual and cognitive abilities. Chassot [14] emphasizes the importance of students' understanding of concepts, so that they are able to equate and solve real life's problems, with autonomy and critical thinking, so necessary for Scientific Literacy.

In this sense, Vessentini [15] clarifies that
The teacher must adapt his course to the students' reality (...). If the students are fascinated by computers, by the image instead of writing, by games, then it is interesting to incorporate all this in the teaching strategy, after all, the teacher is also a citizen who lives in the same world full of changes in the student, he you must also be aware of and participate in technological innovations, cultural changes. (...) It is important to work with these resources in a critical way, leading the student to use them actively (and not merely passively). But written language cannot be neglected, as it represents a whole cultural heritage of humanity ([15], p. 30, our translation).

When presenting problem situations, a teacher has to exercise a mediator's role and allow students to exercise various skills, including logical reasoning, creativity and interpersonal relationships [16]. Indeed, a combination of a problem situation with Geography content, allows students to work with something concrete, practical and interdisciplinary, so that students discover common points among disciplines, and it enables them to exchange experiences.

In this context, games emerge as an educational alternative, as they encourage teamwork and interaction among students and teacher, also it promotes development of skills, logical reasoning and learning of concepts [17]. Games have become very popular these days since they are used in middle and high school around the world serving as an improvement tool for active learning, capable of promoting creativity and collaboration to solve problems, favoring players' scientific literacy.

In this scenario, Minecraft $\AA$ presents itself as an option, as it is an electronic game created by the Swiss Markus Persson, in 2009, that allows construction of imaginary virtual worlds and a reproduction of something real through cubes, such as a puzzle, shared on a network [18].

\section{MethodolOGY}

This research has a qualitative-descriptive approach, since observation, analysis and comparison of data were used to obtain results and the description of what was researched and studied.

The present research was applied in a class with 26 students of the $7^{\text {th }}$ year of Middle School, from a private school in the interior of the State of São Paulo. Due to social distance restriction, caused by the pandemic of Covid-19 in 2020, all interaction stages between teacher and students, as well as students with their peers, were carried out remotely through the Microsoft Teams ${ }^{\circledR}$ platform. The interactions happened during Geography classes, since it was the subject chosen by the school teachers during this period.

Data collection was carried out by observing the researchers, duly authorized by the institution during the presentations, throughout the process of organizing and developing the project by students' chat created for each group within the Microsoft Teams ${ }^{\circledR}$ platform. Thereafter, a questionnaire was applied by teachers via Microsoft Forms ${ }^{\circledR}$ in two sections, one for self-assessment and peer evaluation and another to ascertain the assimilated contents. 
In their projects, students searched data by Brazilian regions on the Brazilian Institute of Geography and Statistics (IBGE) website and organized them in the Microsoft Office Excel. In order to localize important places in Brazil, and get to know sights, they used Google Earth Pro ${ }^{\circledR}$ and Google Maps ${ }^{\circledR}$. Aiming to present the researched data and a "world" built in the Minecraft ${ }^{\circledR}$ game, a Microsoft Office PowerPoint ${ }^{\circledR}$ was used by students to produce and edit videos.

The research was carried out in 8 stages, as shown below:

\section{Stage 1}

- Teachers' presentation of project to students. What do we do? Via platform Microsoft Teams ${ }^{\circledR}$;

- Students divided into 5 groups, one for each region of Brazil: North; Northeast; Central-West; Southeast and South Group.

\section{Stage 2}

- Presentation of the Minecraft ${ }^{\circledR}$ Game by teacher to students and a proposal to build a "world" with touristicand/or important places in each Brazilian region;

- Demonstration of IBGE website also a step by step process of how statistical data were collected: gentile from the states; state capital; estimated population in 2020; estimated demographic density 2020 (it was necessary to calculate it, as there was no such data on the website); average HDI;

- Place's structure and transformation, through mathematical calculations, of data by states into regional data (each group with its region). Activity started in class and ended as a task by students.

\section{Stage 3}

- Communication by groups of tourist points, buildings or mainly natural aspects, relevant and/or important, from each region of Brazil, chosen by students to present in the project;

- Guidance for building virtual environments demonstrating various features by Google Earth Pro ${ }^{\circledR}$ and Google Maps ${ }^{\circledR}$ tools;

- Game's development (sometimes during geography classes and when needed it was complemented by extra-class activity) by students.

\section{Stage 4}

- Data correction and sharing collected by groups in the third item of stage 2 and formulation of a single table with all regions (prepared by a teacher together with students, then made available in groups on Microsoft Teams ${ }^{\circledR}$ platform);

- Use of data in a table to create a ranking containing the following data per region: number of inhabitants; territorial area; demographic density; HDI. The groups made use of this data to assemble their presentations.

\section{Stage 5}

- Guidance by teacher for groups presentations, which occurred in three moments as follows: $1^{\text {st }}$ part - placement of the region worked on legacy items in part 2 of the $4^{\text {th }}$ stage;

- $2^{\text {nd }}$ part - comparison (photo or print) between the environment built in the game and the real one, beyond of presenting information of the respective chosen locations;

- $3^{\text {rd }}$ part - demonstration of the "world" created in the game;

- Every step was performed outside class.

\section{Stage 6}

- Socialization of built environments and information collected by each group from different regions of Brazil through presentation and travel through Brazil in a virtual environment;

- Groups: South, Southeast and Midwest (10/23/2020);

- Groups: North and Northeast (11/06/2020).

Stage 7

- Production of an edited video containing presentations of all groups as a final product (extra class).

\section{Stage 8}

- Data collection through a questionnaire in Microsoft Forms ${ }^{\circledR}$ and by direct observation to monitor participation and class presentation.

\section{RESUlTS AND DisCUSSIONS}

The results are presented according to the research's direct observation, beyond of student's answers obtained by questionnaires divided in two sections, i) self-assessment and peer assessment and ii) specific geography contents worked on during project's application.

A direct observation during the presentation of the three groups on the first day, October $23^{\text {rd }}, 2020$, revealed that South and Southeast groups surprisely presented a high quality of slides, as well as orality, and videos produced of different places built by groups in the game. Differently, the Midwest group showed difficulties in preparing slides and building a game, and they were given the opportunity to redo it, with geography teacher's helpness, and present it again, but at this time with Northeast and North groups.

At the second day, November 06, 2020, it was North group turn, Northeast group and a re-presentation of the reformulated work by Midwest group. During the presentation, there was a technical problem (internet connection). As a consequence, Midwest group presented their video in the next Geography class. The Northeast group performed all data collection and some proposed activities, however, did not create the world in the game, not present it. Although North region group started building the world in the game, a team member responsible for game construction had health problems and needed an absence, the group then contacted teacher and sought alternatives. With teacher's agreement, the group presented monuments and sights using Google Earth Pro instead.

Groups' presentation consisted of the following tourist spots and the respective Brazilian regions, as shown below:

- South Region: Estádio Beira Rio (RS); Jardim Botânico (RS); Colégio Santa Dorotéria (PR);

- Southeast Region: MASP (SP), FIESP (SP), Autódromo de Interlagos (SP); Av. Paulista (SP); Copacabana (RJ); Cristo Redentor (RJ); Pão de Açúcar (RJ); Igreja Tiradentes (MG); Convento da Penha (ES); Vila Velha (ES);

- Midwest Region: Congresso Nacional (DF); Pantanal (MT e MS); Fronteira Agrícola; Templo de Brasília (DF);

- North Region: Teatro Amazonas (AM); Parque Estadual Jalapão (TO); Mercado Cultural de Porto Velho (RO); Marco Zero (AP).

- North East Region: There was no representation.

The students' creations using the Minecraft game during the project are illustrated in Fig. 1. Due to the large amount 
of representations and constructions, a compilation of a few student's productions is exposed here.

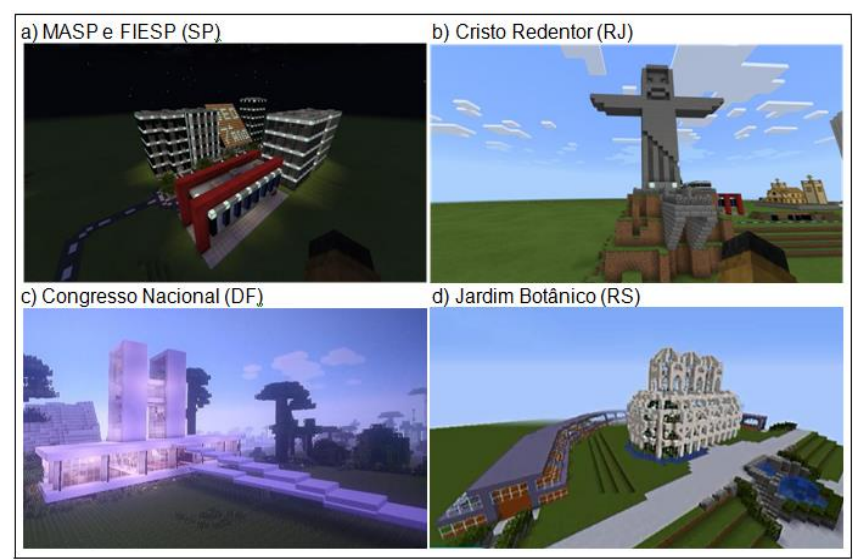

Fig. 1. Representation of constructions made by students.

Through direct observation and follow-ups via chat on the platform, it was found by teachers that groups were able to conduct research on the IBGE website and demonstrated characteristics of each Brazilian region in terms of the gentile and the capitals of each state, average of the Human Development Index (HDI) and estimated population density in 2020 .

Thereafter, groups elaborated projects and made presentation to other colleagues to communicate how and what they learned through the Digital Educational Technologies, which characterizes the purpose of Educommunication.

The interaction among students and the mediation by teacher during the execution of the project seemed to be essential for the development of activities, causing greater confidence for students when developing a proposal. However, the process did not always occur in a harmonious way, because at a given moment, a group felt unsure when watching presentations of previous groups, reporting that their work was, in a way, inferior. At that moment, teacher intervened and reinforced the group project positive points reconquering the group confidence whose accepted the challenge of preparing a new presentation. For that group it was given another opportunity to resubmit the work a week after.

Only one (Northeast Region) out of five groups was unable to complete the project with a presentation of the game due to the lack of interest and commitment given the difficulty in developing the constructions, even with the help, motivation, and intervention of the teacher.

As described previously, to carry out this educommunicative project, students were separated in groups, received a proposal to transmit knowledge, which they built through researches and studies. Their production was carried out through a virtual game, which aimed to benefit their involvement and learning process.

The post-execution questionnaire of the project was made available to 26 students and answered by 16 , during a 50 minute geography class. The first section, consisting of 6 selfassessment and peer-review questions, demonstrated a positive result (feedback), as shown in Fig. 2.

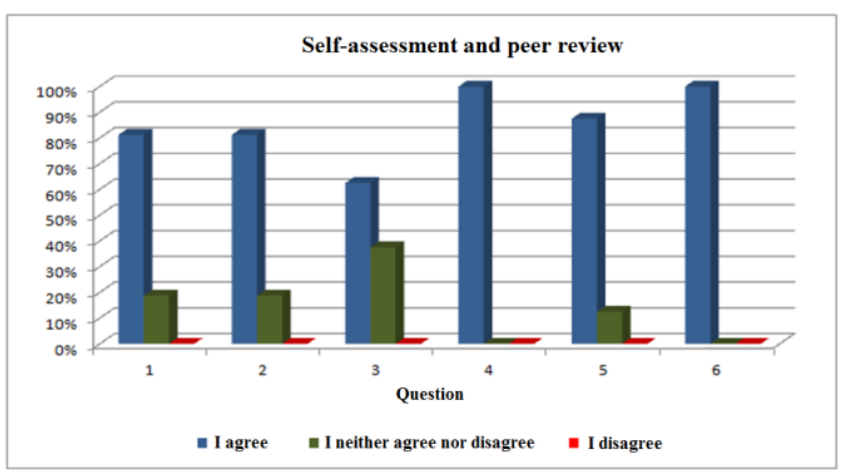

Fig. 2. Graph with students' perception.

In question 1 (My group collaborated, helping each other, during the project) it is clear that there was collaboration among the group members, since $81 \%$ agreed that their peers had collaborative postures. The execution of the project using the TDIC favored the social interaction among students, besides corroborating for the development of the collaborative spirit between them. An essential feature in the learning process and much required in the current and globalized world.

Question 2 sought to assess the student's perception of their own participation through the statement (I participated actively with the group during the project). It was found that $81 \%$ replied that participated actively in the elaboration and execution of the work. The use of educommunication combined with the game allowed students to take an active stance, that is, an agent that builds their own knowledge within the learning process.

In question 3 (I liked and felt challenged to learn by building through online/virtual games) and in question 4 (The project made possible a more fun learning also pleasurable). It was observed that $63 \%$ of students felt challenged and $100 \%$ agreed that the activity involving online/virtual games made their learning process funny and enjoyable. The execution of didactic sequence involving games and technological tools was able to make a learning process more engaging and challenging, and at the same time pleasant and fun, essential factors for a construction of meaningful knowledge.

In the answers to question 5 (I learned new technological tools "Excel, Google Earth Pro, Google Maps, etc." along this project), it is verified that $88 \%$ of students believed they have learned to make proper use of new technological tools. This project, by using TDIC, enabled an expansion of students' interaction with the technological world, supporting skills so required in a globalized world and experienced by today's society.

As for question 6 (I learned to search for Brazilian data by regions from reliable sources) it was found that all students believed they have learned to conduct research and seek statistical and geographical information about Brazil from reliable sources. Given the great availability and easy student's access to media, especially on social networks and sites without credibility, the project was beneficial for critical-scientific and reflective thinking about the need to seek data from reliable sources. Also, checking the works before a presentation with group members or even socializing with colleagues afterwards. 
The second section, consisting of 4 questions, sought to evaluate students' assimilated content related to Geography subject. In addition, to verify whether the learning process flowed according to teacher's teaching plan and in compliance with Common National Curricular Base (BNCC). For the analysis of this section, the rubric according to Table I was utilized.

TABLE I: RUBRIC FOR ANALYZING AND CLASSIFYING STUDENT RESPONSES IN THE SECOND SECTION OF THE QUESTIONNAIRE.

\begin{tabular}{|c|c|c|c|c|}
\hline & $\begin{array}{l}\text { Unsatisfactory } \\
\text { (1 point) }\end{array}$ & $\begin{array}{l}\text { Regular } \\
\text { (2 points) }\end{array}$ & $\begin{array}{l}\text { Satisfactory } \\
\text { (3 points) }\end{array}$ & $\begin{array}{l}\text { Excellent } \\
(4 \text { points })\end{array}$ \\
\hline $\begin{array}{l}\text { Question } \\
1\end{array}$ & $\begin{array}{l}\text { Identify the most OR less } \\
\text { populous region. }\end{array}$ & $\begin{array}{l}\text { Identify the most AND less } \\
\text { populous region. }\end{array}$ & $\begin{array}{l}\text { In addition to the previous item, } \\
\text { identify the position of the region } \\
\text { worked in relation to the others. }\end{array}$ & $\begin{array}{l}\text { Answer the previous items and } \\
\text { identify the ranking of the regions } \\
\text { in relation to the number of } \\
\text { inhabitants. }\end{array}$ \\
\hline $\begin{array}{l}\text { Question } \\
2\end{array}$ & $\begin{array}{l}\text { Do not respond or identify } \\
\text { landscapes of up to } 3 \text { regions. }\end{array}$ & $\begin{array}{l}\text { Correctly identify at least } 1 \\
\text { landscape in each region. }\end{array}$ & $\begin{array}{l}\text { Identify a landscape and a } \\
\text { monument for each region. }\end{array}$ & $\begin{array}{c}\text { Achieve what was requested in the } \\
\text { previous item and relate the } \\
\text { differences in natural and cultural } \\
\text { landscapes. }\end{array}$ \\
\hline $\begin{array}{l}\text { Question } \\
3\end{array}$ & $\begin{array}{l}\text { Explain that demographic } \\
\text { density is the relationship } \\
\text { between the total inhabitants by } \\
\text { the territorial area. }\end{array}$ & $\begin{array}{l}\text { In addition to explaining what } \\
\text { demographic density is and } \\
\text { having presented the formula } \\
\text { Demographic Density }=\text { number } \\
\text { of inhabitants / area }\left(\mathrm{km}^{2}\right) \text {. }\end{array}$ & $\begin{array}{l}\text { In addition to having achieved } \\
\text { what was requested in the } \\
\text { previous item and having hit the } \\
\text { region, it was also associated with } \\
\text { the demographic density with the } \\
\text { term populated. }\end{array}$ & $\begin{array}{l}\text { If the student has already reached a } \\
\text { satisfactory level, it will be } \\
\text { excellent if he is able to associate } \\
\text { the demographic density with } \\
\text { historical, physical and / or } \\
\text { economic factors. }\end{array}$ \\
\hline $\begin{array}{l}\text { Question } \\
4\end{array}$ & $\begin{array}{l}\text { Hit the region with the highest } \\
\text { OR lowest HDI in Brazil. }\end{array}$ & $\begin{array}{l}\text { Hit the region with the highest } \\
\text { AND lowest HDI in Brazil. }\end{array}$ & $\begin{array}{l}\text { If regular, associate the HDI with } \\
\text { at least } 1 \text { index. }\end{array}$ & $\begin{array}{l}\text { If satisfactory, associate the HDI } \\
\text { with quality of life, education and } \\
\text { health. }\end{array}$ \\
\hline
\end{tabular}

After a verification of the second section of questionnaires answered by students and teacher class leader compilation, the results obtained, based on Chart 3, are shown in Fig. 3.

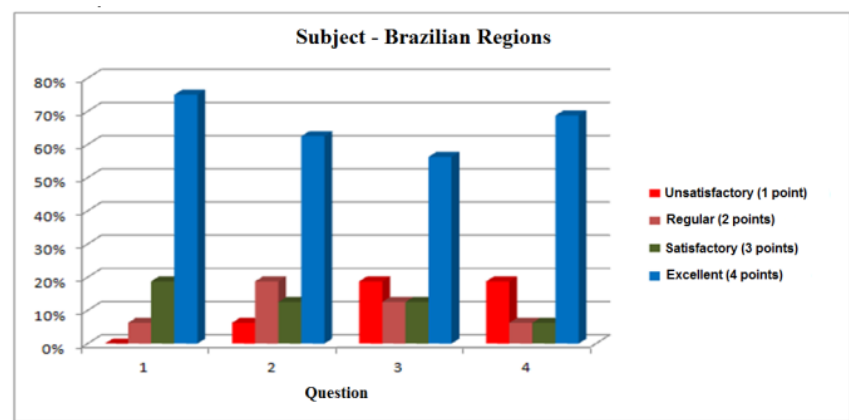

Fig. 3. Graph with results of Geography's contents assimilated by students after project accomplishment.

Question 1 (Regarding the Brazilian population, which region has the largest number of inhabitants? Which region has the lowest number of inhabitants? Compare all regions with that of your group). This question allowed the authors of this research to verify that $75 \%$ of students managed to reach an outstanding level, which is 4 points, according to the rubric (Table I).

The project provided an opportunity for students to understand a concept of absolute population, which led them to classify and verify irregularities in inhabitants' distribution in different Brazilian regions. It also assists them to understand territorial structure and its connections with the physical-natural and human aspects.

In the answers for Question 2 (Cite at least one landscape and a monument from each Brazilian region. Compare them by commenting on the differences in the natural and cultural landscapes of the Brazilian regions). It was found that $63 \%$ reached 4 points. In fact, technological resources applied to know different places and landscapes through a virtual trip, provided students a better perception of the region landscape. This fact gains significance as they observe different regional characteristics and the interference of human beings in the relationship with the environment they live.
It was noted that in Question 3 (The regions of Brazil have different Demographic Densities, that is, some regions are more populated and others less. a) But, after all, what is Demographic Density? Give an example with a mathematical formula; b) Look at the table (containing the absolute population and the area in $\mathrm{km}^{2}$ for them to calculate the demographic density) and answer. What is the most populated region?; c) Cite a reason for the inequality in the Demographic Density between the Brazilian regions). It was observed that, the percentage of students that reached an excellent level was $56 \%$, while $19 \%$ were evaluated as unsatisfactory.

The project favored the understanding of the concepts of relative population and population directly linked to the calculation of demographic density and related them to the historical, physical and economic process in the territorial formation of Brazil, as well as the unequal use of the territory. However, the results demonstrate the possibility of improving the project in activities aimed at this content, aiming to reach those who did not reach the satisfactory and excellent level.

In Question 4 (Which region has the best HDI? And the worst HDI? What does that mean? What are the indicators used to measure the HDI?) It was found that $69 \%$ were able to respond with excellence, reporting inequalities between Brazilian regions and associate them with Human Development Index (HDI), specifically in terms of quality of life, health, and education of the population. It is noted that the projects provided to students a critical-scientific spirit by analyzing three relevant aspects for the development of each region of Brazil. Also, making them agents capable of identifying the economic and social disparities of the population of the country.

In this work, educommunication was revealed as a facilitator that contributes to Scientific Literacy on Geography teaching. Students were able to reach their aims through research and elaboration toward educational and communication projects. They also managed to promote scientific dissemination in an interactive process that was established among groups. A process based on problem solving, studies, exchange of information and encouragement 
in the construction of knowledge without prevailing the competitive climate was obtained successfully.

\section{FINAL CONSIDERATIONS}

When it comes to education, a challenge includes a positioning and stance that educational environment has to assume in face of technological innovations. Challenge that has ended up to incorporating TDIC and its transformations in formal and informal education.

The experience of this research, involving Educommunication, made possible to verify students' motivation and engagement in research also in understanding science, specifically in Geography, revealing that knowledge is not an accumulation of information. Indeed, a hypermedia is a valuable tool to remove a student from a passive position of content recipient to an active place, as an interactive and creative learner.

It is interesting to note that Minecraft $\AA$, which was not developed for educational purposes, fulfilled necessary learning requirements, being able to give players a voice by creating modifications within the game, and ultimately imposing new challenges and stimulating knowledge in a playful way.

To sum up, the results showed that active learning, through problem situations proposed in classes, and appropriate tools, which encouraged students to take attitude for diligent subjects when seeking solutions, led them to consider the local reality, and to know the environment that surrounds them.

The use of Educommunication in this research, as a Digital Information Technologies and Communication tool applied to education, allowed a break of a traditional teaching practices, being a mediating instrument that motivate a generation of digital natives to be closer to teaching, promoting interdisciplinarity also enriching students' knowledge.

\section{REFERENCES}

[1] Bauman, Z. Tempos líquidos. Tradução de Carlos Alberto Medeiros. Rio de Janeiro: Jorge Zahar, 2007.

[2] Prensky, M. Digital game-based learning: practical ideas for the application of digital game-based learning. St. Paul, MN: Paragon House, 2007.

[3] Moraes, C. R. E.; Varela, S. Motivação do aluno durante o processo de ensino-aprendizagem. Revista Eletrônica de Educação. Ano I, n. 01 , ago-dez, 2007. Disponível em

https://web.unifil.br/docs/revista_eletronica/educacao/Artigo_06.pdf Acesso em 03 nov 2020.

[4] Brasil. Ministério da Saúde. COVID-19 Coronavirus. Brasília. 2020. Disponível em https://coronavirus.saude.gov.br Acesso em 27 mar 2020.

[5] Brasil. Ministério da Educação e Cultura. Base Nacional Comum Curricular-BNCC. Brasília. 2017.

[6] Sartori, A. S. Inter-relações entre comunicação e educação: a educomunicação e a gestão dos fluxos comunicacionais. In: UNIrevista, vol. 1 , n. 3, julho/2006.

[7] Perrenoud, P. Dez Novas Competências para Ensinar. Porto Alegre: Artmed. 2000.

[8] Soares, I. de O. Educomunicação: o conceito, o profissional, a aplicação. São Paulo: Paulinas, 2011.

[9] Soares, I. de O. Alfabetização e Educomunicação: o papel dos meios de comunicação e informação na educação de jovens e adultos ao longo da vida. In: III Telecongresso Internacional de Educação de Jovens e Adultos, 3. 2003. Disponível em

http://www.usp.br/nce/wcp/arq/textos/89.pdf Acesso em 12 out 2020.
[10] Kenski, V. M. Educação e Tecnologias: o novo ritmo da informação. 8. ed. Campinas, SP: Papirus, 2012.

[11] Lévy, P. Cibercultura. São Paulo: Ed. 34, 2000.

[12] Zabala, A. A prática educativa: como ensinar. Tradução de Ernani F. da F. Rosa. Porto Alegre: Artmed, 1998.

[13] Oliveira, M. M. de. Sequência didática interativa no processo de formação de professores. Petrópolis, RJ: Vozes, 2013.

[14] Chassot, A. Alfabetização Científica - Questões e Desafios para a Educação, Ijuí, Editora da Unijuí. 2000.

[15] Vessentini, J. W. (org.) Geografia e Ensino. Textos Críticos. $7^{\mathrm{a}}$ Ed. Campinas: Papirus, 2003.

[16] Feitosa, J. G. Material Didático Pedagógico. 1 ed. Curitiba, PR: Zoom Editora Educacional, 2013.

[17] Vygotsky, L. A formação social da mente. São Paulo: Martins Fontes, 1989.

[18] Persson, M. N. Minecraft. Mojang Studios, Microsoft. 2014. Disponível em www.minecraft.net Acesso em 15 out 2020.

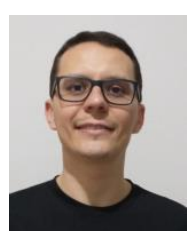

Émerson dos Reis Pereira is Geography Teacher in Middle School. Graduated in Social Studies with qualification in Geography at Integrated Colleges of Cruzeiro (FIC). Graduated in Science at University of São Paulo (USP) with specialization in environmental management at the Salesian University Center of São Paulo (UNISAL). He has experience in the area of Geography and Environment education and in the area of Research and Data Collection through electronic equipment as a Research and Mapping Agent at the Brazilian Institute of Geography and Statistics - IBGE. Master's student in Educational Science Projects at the University of São Paulo (USP).

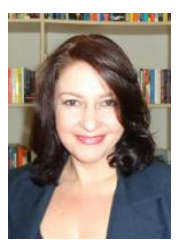

Andréa Goulart Mendes Carruba graduated in Social Communication at the University of Taubaté (UNITAU) with specialization in Advertising and Publicity, with an emphasis in Marketing. Graduated in Psychology at the Salesian University Center (UNISAL), with an emphasis on Education and Social Commitment. She has experience in Clinical and School Psychology working in the Analytical Psychology approach. Master's student in Educational Science Projects at the University of São Paulo (USP).

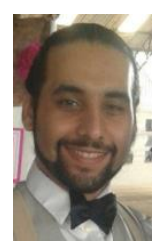

Adam Gonçalves Zeni de Oliveira is Physical Education teacher in the public network of the city of Lorena. Graduated in Licentiate and Bachelor of Physical Education from the Superior School of Physical Education of Cruzeiro (ESEFIC). Specialization in Exercise Physiology and Prescription Training by the University Center of Faculdade Metropolitana Unidas (FMU). He has experience in the field of education with projects and in the field of sports training. Master's student in Education Science Projects at the University of São Paulo (USP).

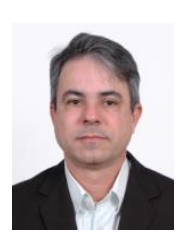

Jairo A Martins is a Doctor in Philosophy (Ph.D.) in Mechanical Engineering by University of State of Campinas (Unicamp) in 2004 and post-doctoral fellow at University of São Paulo (USP) 2016, both in Brazil. He works as Research \& Development Manager at DESCH in Canada. Dr. Martins main field of study is mechanics and material science, among them; machine engineering design, x-ray diffraction, residual stress, fracture, fatigue, finite element analysis (linear and non-linear) and manufacturing processes.

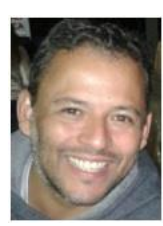

Estaner Claro Romão is a Doctor in Philosophy (Ph.D.) in Mechanical Engineering by University of State of Campinas (Unicamp) in 2011 and post-doctoral fellow at UNICAMP 2013, both in Brazil. He currently works in two lines of research: Teaching Mathematics and Science and Numerical Simulation of Transfer Problems and Heat and Mass and Solid Mechanics. He is currently an Associate Professor at the University of São Paulo, Escola de Engenharia de Lorena. 